\title{
Acid-base and metal ion binding properties of 2-thiocytidine in aqueous solution
}

\author{
Justyna Brasuń · Agnieszka Matera · Elżbieta Sochacka • \\ Jolanta Swiatek-Kozlowska · Henryk Kozlowski · \\ Bert P. Operschall $\cdot$ Helmut Sigel
}

Received: 16 November 2007 / Accepted: 7 February 2008/ Published online: 29 February 2008

(c) SBIC 2008

\begin{abstract}
The thionucleoside 2-thiocytidine (C2S) occurs in nature in transfer RNAs; it receives attention in diverse fields like drug research and nanotechnology. By potentiometric $\mathrm{pH}$ titrations we measured the acidity constants of $\mathrm{H}(\mathrm{C} 2 \mathrm{~S})^{+}$and the stability constants of the $\mathrm{M}(\mathrm{C} 2 \mathrm{~S})^{2+}$ and $\mathrm{M}(\mathrm{C} 2 \mathrm{~S}-\mathrm{H})^{+}$complexes $\left(\mathrm{M}^{2+}=\mathrm{Zn}^{2+}, \mathrm{Cd}^{2+}\right)$, and we

Species written without a charge either do not carry one or represent the species in general (i.e., independent of their protonation degree); which of the two possibilities applies is always clear from the context. A formula like $(\mathrm{C} 2 \mathrm{~S}-\mathrm{H})^{+}$means that the ligand has lost a proton and it is to be read as $\mathrm{C} 2 \mathrm{~S}$ minus $\mathrm{H}^{+}$.
\end{abstract}

J. Brasuń $(\varangle) \cdot$ A. Matera · J. Swiatek-Kozlowska

Department of Inorganic Chemistry,

Wroclaw Medical University,

Szewska 38,

50-139 Wroclaw, Poland

e-mail: jbrasun@chnorg.am.wroc.pl

E. Sochacka

Department of Organic Chemistry,

Technical University of Lodz,

Zeromskiego 116,

90-924 Lodz, Poland

e-mail: elzbieta.sochacka@p.lodz.pl

H. Kozlowski

Faculty of Chemistry,

University of Wroclaw,

F. Joliot Curie,

50-383 Wroclaw, Poland

B. P. Operschall · H. Sigel $(\bowtie)$

Department of Chemistry, Inorganic Chemistry,

University of Basel,

Spitalstrasse 51,

4056 Basel, Switzerland

e-mail: helmut.sigel@unibas.ch compared these results with those obtained previously for its parent nucleoside, cytidine (Cyd). Replacement of the $(\mathrm{C} 2)=\mathrm{O}$ unit by $(\mathrm{C} 2)=\mathrm{S}$ facilitates the release of the proton from $(\mathrm{N} 3) \mathrm{H}^{+}$in $\mathrm{H}(\mathrm{C} 2 \mathrm{~S})^{+}\left(\mathrm{p} K_{\mathrm{a}}=3.44\right)$ somewhat, compared with $\mathrm{H}(\mathrm{Cyd})^{+}\left(\mathrm{p} K_{\mathrm{a}}=4.24\right)$. This moderate effect of about $0.8 \mathrm{pK}$ units contrasts with the strong acidification of about $4 \mathrm{p} K$ units of the $(\mathrm{C} 4) \mathrm{NH}_{2}$ group in $\mathrm{C} 2 \mathrm{~S}\left(\mathrm{p} K_{\mathrm{a}}=\right.$ 12.65) compared with Cyd $\left(\mathrm{p} K_{\mathrm{a}} \approx 16.7\right)$; the reason for this result is that the amino-thione tautomer, which dominates for the neutral $\mathrm{C} 2 \mathrm{~S}$ molecule, is transformed upon deprotonation into the imino-thioate form with the negative charge largely located on the sulfur. In the $\mathrm{M}(\mathrm{C} 2 \mathrm{~S})^{2+}$ complexes the $(\mathrm{C} 2) \mathrm{S}$ group is the primary binding site rather than $\mathrm{N} 3$ as is the case in the $\mathrm{M}(\mathrm{Cyd})^{2+}$ complexes, though owing to chelate formation N3 is to some extent still involved in metal ion binding. Similarly, in the $\mathrm{Zn}(\mathrm{C} 2 \mathrm{~S}-\mathrm{H})^{+}$and $\mathrm{Cd}(\mathrm{C} 2 \mathrm{~S}-\mathrm{H})^{+}$complexes the main metal ion binding site is the $(\mathrm{C} 2) \mathrm{S}^{-}$unit (formation degree above 99.99\% compared with that of N3). However, again a large degree of chelate formation with N3 must be surmised for the $\mathrm{M}(\mathrm{C} 2 \mathrm{~S}-\mathrm{H})^{+}$species in accord with previous solid-state studies of related ligands. Upon metal ion binding, the deprotonation of the $(\mathrm{C} 4) \mathrm{NH}_{2}$ group $\left(\mathrm{p} K_{\mathrm{a}}=12.65\right)$ is dramatically acidified ( $\mathrm{p} K_{\mathrm{a}} \approx 3$ ), confirming the very high stability of the $\mathrm{M}(\mathrm{C} 2 \mathrm{~S}-\mathrm{H})^{+}$complexes. To conclude, the hydrogen-bonding and metal ion complex forming capabilities of $\mathrm{C} 2 \mathrm{~S}$ differ strongly from those of its parent Cyd; this must have consequences for the properties of those RNAs which contain this thionucleoside.

Keywords Acidity constants - Isomeric equilibria . RNAs with thionucleosides - Stability constants . Tautomeric equilibria 


\section{Introduction}

Thioderivatives of nucleobases [1-3] are receiving more and more attention in diverse fields [4-9]. For example, 2thiocytidine (C2S) and related compounds are employed in nanotechnology [4], they are under investigation in drug research [5], and they occur in nature as well [6]. Such compounds are used as corrosion inhibitors [7], and also in the preparation of sensors, e.g., self-assembled monolayers of $\mathrm{C} 2 \mathrm{~S}$ on a gold electrode allow the voltammetric detection of NADH [4] and other compounds as well [8,9].

$\mathrm{C} 2 \mathrm{~S}$ and various derivatives are potential drugs [5] and are tested for their antiviral [10] and antitumor [11] activities. In this context it is interesting to see that uridinecytidine kinases are able to phosphorylate 4-thiouridine, $\mathrm{C} 2 \mathrm{~S}$, and some other related nucleoside derivatives [5]. Indeed, most nucleoside analogues are dependent on phosphorylation to their triphosphate form for pharmacological activity [12-14]. Needless to emphasize, such phosphorylation (and also dephosphorylation) reactions depend on the presence of metal ions [13,15].

In nature, e.g., transfer RNA from Salmonella enterica sv. Typhimurium contains five thiolated nucleosides, C2S (Fig. 1) [16-18] being one of them [6]. Most of these thio derivatives, including C2S, also occur in Escherichia coli $[19,20]$. Regarding the formation of $\mathrm{C} 2 \mathrm{~S}$, it has been shown that iron-sulfur cluster proteins are involved $[19,21]$.
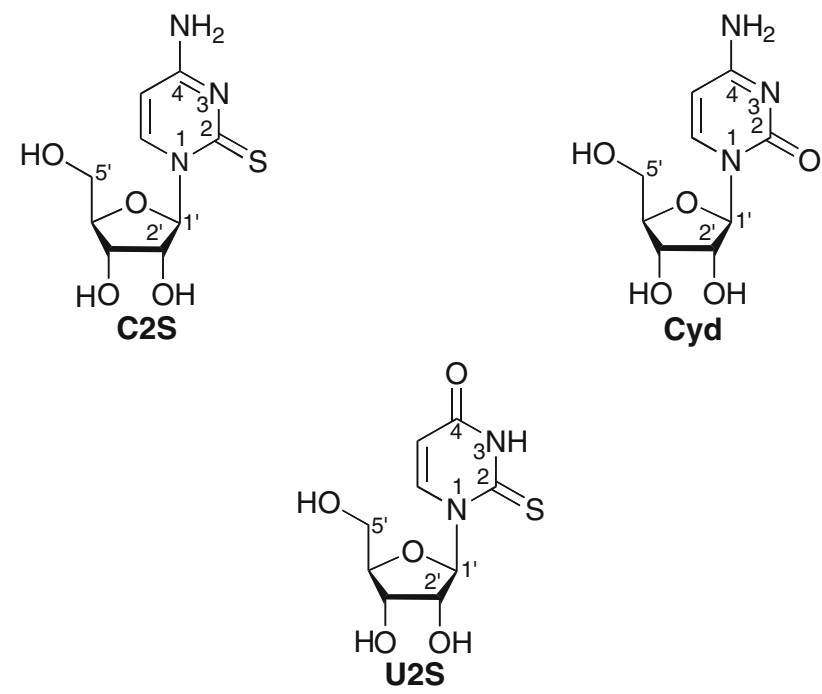

Fig. 1 Chemical structures of 2-thiocytidine $(C 2 S)$ and of its parent compound, cytidine $(C y d)$, as well as of the related 2-thiouridine $(U 2 S)$. It may be added that semiempirical calculations [16] predict for the 1-methyl derivative of 2-thiocytosine that the thione-amino tautomer (as shown above) is the most stable form in the gas and the aqueous phase as well. All three pyrimidine nucleosides are shown in their dominating anti conformation [17, 18]; in the syn conformation the $(\mathrm{C} 2) \mathrm{O} /(\mathrm{C} 2) \mathrm{S}$ group projects onto the ribose ring
Considering the indicated occurrence and wide use of $\mathrm{C} 2 \mathrm{~S}$ and the evident involvement of metal ions in reactions where this nucleoside participates, it is astonishing to find that its metal ion binding properties have not been determined [22-24]. As a first step we report now the acid-base properties of $\mathrm{C} 2 \mathrm{~S}$ and its affinity towards $\mathrm{Zn}^{2+}$ and $\mathrm{Cd}^{2+}$. We compare these results with the corresponding equilibrium constants obtained earlier for the parent nucleoside, cytidine (Cyd) (Fig. 1) [25, 26], and we use this information to delineate structural information about these complexes in aqueous solution. It becomes evident that the replacement of $(\mathrm{C} 2) \mathrm{O}$ by $(\mathrm{C} 2) \mathrm{S}$ affects the acid-base and metal ion-binding properties considerably.

\section{Materials and methods}

Materials and synthesis of $\mathrm{C} 2 \mathrm{~S}$

$\mathrm{C} 2 \mathrm{~S}$ was synthesized as described below. The nitrate salts of $\mathrm{K}^{+}$and $\mathrm{Zn}^{2+}$ as well as $\mathrm{NaOH}$ and $\mathrm{HNO}_{3}$ were obtained from Merck; the nitrate salt of $\mathrm{Cd}^{2+}$ was from Sigma-Aldrich.

The nucleoside analogue $\mathrm{C} 2 \mathrm{~S}$ was obtained by the transformation of $2^{\prime}, 3^{\prime}, 5^{\prime}$-tri- $O$-benzoyl-2-thiouridine into the 4-(1,2,4-triazol-1-yl) derivative followed by its ammonolysis and deprotection. In the first step the per-benzoyl derivative of 2-thiouridine was reacted with a mixture of phosphoryl chloride, 1,2,4-triazole, and triethylamine in acetonitrile, providing quantitatively the 4-triazoyl derivative of 2-thiouridine. Ammonolysis of the triazoyl group and deprotection of the benzoyl groups from the sugar moiety were achieved simultaneously by treatment with a half-saturated $\mathrm{NH}_{3}$ /methanol solution (overnight, room temperature). $\mathrm{C} 2 \mathrm{~S}$ was isolated in $73 \%$ yield after purification by means of silica gel chromatography $\left(\mathrm{CHCl}_{3} /\right.$ methanol, $8: 2, \mathrm{v} / \mathrm{v})$. The structure of $\mathrm{C} 2 \mathrm{~S}$ was confirmed by ${ }^{1} \mathrm{H}$ NMR and mass spectrometry.

\section{Potentiometric $\mathrm{pH}$ titrations}

The equilibrium constants were determined from titrations at $25{ }^{\circ} \mathrm{C}$, using sample volumes of $1.5 \mathrm{~mL}$. Sodium hydroxide was added with a $0.25-\mathrm{mL}$ micrometer syringe, calibrated by weight titration of standard materials. The ligand concentration was $0.4 \mathrm{mM}$, and the metal-to-ligand ratio was 5:1 for the $\mathrm{Cd}^{2+}$ and 15:1 for the $\mathrm{Zn}^{2+}$ system.

The potentiometric $\mathrm{pH}$ titrations were performed in $0.5 \mathrm{M} \mathrm{KNO}_{3}$ with a MOLSPIN pH-meter system using a Mettler Toledo InLab 422 semimicro combined electrode, calibrated for hydrogen ion concentration using $\mathrm{HNO}_{3}$. The stability constants $\beta_{p q r}=\left[\mathrm{M}_{p} \mathrm{H}_{q} \mathrm{~L}_{r}\right] /[\mathrm{M}]^{p}[\mathrm{H}]^{q}[\mathrm{~L}]^{r}$ and the stoichiometry of the complexes were calculated with the SUPERQUAD program [27]. The standard deviations 
given were also computed with SUPERQUAD; they refer to random errors only. The $\mathrm{pH}$ range for each titration of the free ligand or the metal-ligand systems was 2.2-4.2. Four independent titrations were performed for the determination of the acidity constant of $\mathrm{H}(\mathrm{C} 2 \mathrm{~S})^{+}$as well as for the equilibrium constants of the $\mathrm{M}^{2+} / \mathrm{C} 2 \mathrm{~S}$ systems. All measurements were performed under an argon atmosphere.

Spectrophotometric determination of the acidity constant of the $\mathrm{C} 2 \mathrm{~S}$ species

The acidity constant $K_{\mathrm{C} 2 \mathrm{~S}}^{\mathrm{H}}$ is too high to be determined by potentiometric $\mathrm{pH}$ titrations, but by spectrophotometry in the wavelength range $200-400 \mathrm{~nm}$ the constant could be measured $\left(5 \times 10^{-5} \mathrm{M} \mathrm{C} 2 \mathrm{~S} ; 25{ }^{\circ} \mathrm{C} ; I=0.5 \mathrm{M}, \mathrm{KNO}_{3}\right)$. This value of free $\mathrm{C} 2 \mathrm{~S}$ was calculated using the SPECPEAK program [28]. The program decomposes the absorption spectra into their constituents (Gaussian peaks) by optimizing the wavelengths of the maximum of the individual spectra and their half-band widths. The $\mathrm{p} K$ value was calculated from the trends of the heights of the principal bands as a function of $\mathrm{pH}$.

\section{Results and discussion}

Self-stacking is a well-known phenomenon of purines and pyrimidines and must therefore be considered in any measurements designed for the quantifications of monomeric species [29]. For Cyd, the self-association constant as defined by Eq. 1

$(\mathrm{Cyd})_{n}+\mathrm{Cyd} \rightleftharpoons(\mathrm{Cyd})_{n+1}$

is small $\left(K=1.4 \pm 0.5 \mathrm{M}^{-1}\right)$ [30] and a similar low value is expected for $\mathrm{C} 2 \mathrm{~S}$. As the $\mathrm{C} 2 \mathrm{~S}$ concentrations used in this study were throughout $0.4 \mathrm{mM}$ or below, self-stacking is certainly negligible [30] and all results presented refer to monomeric species.

\section{Acidity constant of monoprotonated C2S}

The pyrimidine derivative $\mathrm{C} 2 \mathrm{~S}$ has only $\mathrm{N} 3$ as a basic site (Fig. 1) and may thus be protonated to $\mathrm{H}(\mathrm{C} 2 \mathrm{~S})^{+}$. Since no other acid-base equilibrium is expected to occur in the physiological pH range, only Eq. 2 needs to be considered:

$\mathrm{H}(\mathrm{C} 2 \mathrm{~S})^{+} \rightleftharpoons \mathrm{H}^{+}+\mathrm{C} 2 \mathrm{~S}$

$K_{\mathrm{H}(\mathrm{C} 2 \mathrm{~S})}^{\mathrm{H}}=\left[\mathrm{H}^{+}\right][\mathrm{C} 2 \mathrm{~S}] /\left[\mathrm{H}(\mathrm{C} 2 \mathrm{~S})^{+}\right]$

The corresponding acidity constant of $\mathrm{H}(\mathrm{C} 2 \mathrm{~S})^{+}$was determined by potentiometric $\mathrm{pH}$ titrations to give as a result $\mathrm{p} K_{\mathrm{H}(\mathrm{C} 2 \mathrm{~S})}^{\mathrm{H}}=3.44 \pm 0.01\left(25^{\circ} \mathrm{C} ; I=0.5 \mathrm{M}, \mathrm{KNO}_{3}\right)$.
This value is by $\Delta \mathrm{p} K_{\mathrm{a}}=0.80 \pm 0.02$ below the acidity constant of $\mathrm{H}(\mathrm{Cyd})^{+}$which was determined earlier as $\mathrm{p} K_{\mathrm{H}(\mathrm{Cyd})}^{\mathrm{H}}=4.24 \pm 0.02\left(25^{\circ} \mathrm{C} ; I=0.5 \mathrm{M}, \mathrm{NaNO}_{3}\right)$ [26]. In fact, the acidification of a nearby basic site owing to the replacement of an oxygen atom by a sulfur atom is a wellknown phenomenon and has been observed for uridine and thiouridine derivatives $[3,31,32]$ as well as for acetic acid/ thioacetic acid [33, 34] and also for phosphoric acids/ thiophosphoric acids $[34,35]$. For example, the difference in acidity at the $(\mathrm{N} 3) \mathrm{H}$ site for uridine $\left(\mathrm{p} K_{\mathrm{a}}=9.18\right)$ and 2thiouridine $\left(\mathrm{p} K_{\mathrm{a}}=8.05\right)$ amounts to about $1.1 \mathrm{p} K$ units [3].

\section{Deprotonation of neutral C2S}

During the potentiometric $\mathrm{pH}$ titrations in the presence of $\mathrm{Zn}^{2+}$ or $\mathrm{Cd}^{2+}$ and after formation of the $\mathrm{M}(\mathrm{C} 2 \mathrm{~S})^{2+}$ complexes it became evident that a further proton is released from the complexes with a $\mathrm{p} K_{\mathrm{a}}$ value of about 3 (see later). Such a low value cannot be attributed to the formation of hydroxo complexes [36] and also not to a metal ion promoted release of a proton from the ribose residue; the ribose deprotonation occurs with $\mathrm{p} K_{\mathrm{a}} \approx 12.5$ [37] and a corresponding strong acidification down to $\mathrm{pH} 3$ is not known [38]. Hence, the proton must be released from the nucleobase residue and its release must be connected with the presence of the sulfur atom at $\mathrm{C} 2$ (Fig. 1). Evidently the only site in question is the (C4) $\mathrm{NH}_{2}$ group; indeed, for Cyd and the related 1-methylcytosine it is known that a very low acidity exists and that a proton can be released from the exocyclic amino group with $\mathrm{p} K_{\mathrm{a}} \approx 16.7$ [37].

From earlier spectrophotometric studies with Cyd [26] it is known that an electronic disturbance in the pyrimidine residue is reflected in the UV absorption in the range of about 240-280 nm. Consequently, we measured the dependence of the UV absorption spectra of $\mathrm{C} 2 \mathrm{~S}$ on $\mathrm{pH}$ (for details see "Materials and methods") and could in this way determine the acidity constant defined in Eq. 3:

$\mathrm{C} 2 \mathrm{~S} \rightleftharpoons(\mathrm{C} 2 \mathrm{~S}-\mathrm{H})^{-}+\mathrm{H}^{+}$

$K_{\mathrm{C} 2 \mathrm{~S}}^{\mathrm{H}}=\left[(\mathrm{C} 2 \mathrm{~S}-\mathrm{H})^{-}\right]\left[\mathrm{H}^{+}\right] /[\mathrm{C} 2 \mathrm{~S}]$

The corresponding result, $\mathrm{p} K_{\mathrm{C} 2 \mathrm{~S}}^{\mathrm{H}}=12.65 \pm 0.12\left(25^{\circ} \mathrm{C} ; I=\right.$ $0.5 \mathrm{M}, \mathrm{KNO}_{3}$ ), shows that deprotonation of the $(\mathrm{C} 4) \mathrm{NH}_{2}$ group is facilitated in $\mathrm{C} 2 \mathrm{~S}$ by about $4 \mathrm{p} K$ units compared with the same reaction in 1-methylcytosine $\left(\mathrm{p} K_{\mathrm{a}} \approx 16.7\right.$ $[37,39])$. This is a very large acidification as is evident from the $\mathrm{p} K_{\mathrm{a}}$ value of 15.1 determined [39] for 5-bromo-1methylcytosine and the corresponding $\Delta \mathrm{p} K_{\mathrm{a}}$ value of 1.6; this is despite the fact that bromine has a higher electronegativity than sulfur [40]. Therefore, the very large acidification observed with $\mathrm{C} 2 \mathrm{~S}$ is most likely linked to the tautomerism discussed later and the reorganization of the charge within the anion. 
<smiles>CC1CC1CC1CC1</smiles>

amino<smiles>[R]n1ccc(=N)nc1S</smiles>

imino

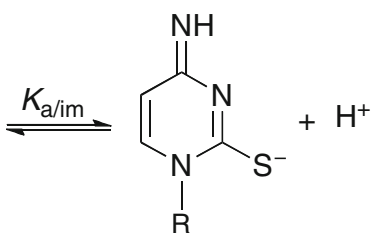

$(\text { imino }-\mathrm{H})^{-}$
Fig. 2 Semiempirical calculations [16, 41, 42] confirm that in aqueous solution $\mathrm{C} 2 \mathrm{~S}$ exists as the amino-thione tautomer (amino) and that the imino-thiol form (imino) is a minority species (Eq. 14). It is concluded (see the text) that upon deprotonation of the amino group of $\mathrm{C} 2 \mathrm{~S}$ (Eqs. 3, 13) a redistribution of charge occurs and that then the thioate form [shown as (imino-H) ${ }^{-}$] dominates (Eq. 15) (see also the text). The other minority species, the imino-thione tautomer with an (N3)H unit [16], is not shown here because it is not of relevance in this context (however, see also the structure in Fig. 5d)

At this point it is helpful to recall that semiempirical calculations for 1-methyl-2-thiocytosine [16] as well as for 2-thiocytosine [41, 42] confirm that in aqueous solution the amino-thione tautomer strongly dominates (Fig. 2). Upon deprotonation of the (C4) $\mathrm{NH}_{2}$ group, we propose, and this is in accord with the properties of the metal ion complexes (see later), that a redistribution of the charge takes place and that this is mainly located on the sulfur atom [see the (imino-H) $)^{-}$form in Fig. 2]. Similar changes in bond order and charge localization take place in thiophosphoric acids upon deprotonation [34] as confirmed by IR and Raman spectroscopic studies [43-45] as well as by semiempirical calculations [34]. Frey and Sammons [46] explained these observations quite generally with the conclusion that "in aqueous solution a negative charge localized on sulfur is less unstable than one localized on oxygen (in our case on nitrogen) ... because the larger size and polarizability of sulfur ... (allow) the charge density in a thiolate anion to be less" when compared with the other anions.

Stability constants of $\mathrm{M}^{2+} / \mathrm{C} 2 \mathrm{~S}$ complexes

As already indicated, the $\mathrm{M}(\mathrm{C} 2 \mathrm{~S})^{2+}$ complexes can lose a proton from the $(\mathrm{C} 4) \mathrm{NH}_{2}$ group. In accord with this, one can completely describe the experimental data from the potentiometric $\mathrm{pH}$ titrations by considering Eqs. 2, 4, and 5:

$\mathrm{M}^{2+}+\mathrm{C} 2 \mathrm{~S} \rightleftharpoons \mathrm{M}(\mathrm{C} 2 \mathrm{~S})^{2+}$

$K_{\mathrm{M}(\mathrm{C} 2 \mathrm{~S})}^{\mathrm{M}}=\left[\mathrm{M}(\mathrm{C} 2 \mathrm{~S})^{2+}\right] /\left(\left[\mathrm{M}^{2+}\right][\mathrm{C} 2 \mathrm{~S}]\right)$

$\mathrm{M}(\mathrm{C} 2 \mathrm{~S})^{2+} \rightleftharpoons \mathrm{M}(\mathrm{C} 2 \mathrm{~S}-\mathrm{H})^{+}+\mathrm{H}^{+}$

$K_{\mathrm{M}(\mathrm{C} 2 \mathrm{~S})}^{\mathrm{H}}=\left[\mathrm{M}(\mathrm{C} 2 \mathrm{~S}-\mathrm{H})^{+}\right]\left[\mathrm{H}^{+}\right] /\left[\mathrm{M}(\mathrm{C} 2 \mathrm{~S})^{2+}\right]$

The stability constants according to Eq. 4 and the acidity constants according to Eq. 5 are listed in columns 2 and 3
Table 1 Logarithms of the stability constants of the $\mathrm{M}(\mathrm{C} 2 \mathrm{~S})^{2+}$ (Eq. 4) and $\mathrm{M}(\mathrm{C} 2 \mathrm{~S}-\mathrm{H})^{+}$(Eq. 6) complexes together with the negative logarithms of the acidity constants of the $\mathrm{M}(\mathrm{C} 2 \mathrm{~S})^{2+}$ species (Eq. 5) as determined by potentiometric $\mathrm{pH}$ titrations in aqueous solution $\left(25{ }^{\circ} \mathrm{C} ; I=0.5 \mathrm{M}, \mathrm{KNO}_{3}\right)$

\begin{tabular}{llll}
\hline $\mathrm{M}^{2+}$ & $\log K_{\mathrm{M}(\mathrm{C} 2 \mathrm{~S})}^{\mathrm{M}}$ & $\mathrm{p} K_{\mathrm{M}(\mathrm{C} 2 \mathrm{~S})}^{\mathrm{H}}$ & $\log K_{\mathrm{M}(\mathrm{C} 2 \mathrm{~S}-\mathrm{H})}^{\mathrm{M}}$ \\
\hline $\mathrm{Zn}^{2+}$ & $2.53 \pm 0.04$ & $3.35 \pm 0.05$ & $11.83 \pm 0.14$ \\
$\mathrm{Cd}^{2+}$ & $3.72 \pm 0.03$ & $3.09 \pm 0.04$ & $13.28 \pm 0.13$ \\
\hline
\end{tabular}

The acidity constants of $\mathrm{H}(\mathrm{C} 2 \mathrm{~S})^{+}$are $\mathrm{p} K_{\mathrm{H}(\mathrm{C} 2 \mathrm{~S})}^{\mathrm{H}}=3.44 \pm 0.01$ and $\mathrm{p} K_{\mathrm{C} 2 \mathrm{~S}}^{\mathrm{H}}=12.65 \pm 0.12$ (see also the corresponding sections)

C2S 2-thiocytidine (see Fig. 1)

of Table 1, respectively. Of course, the existence of Eq. 5 means that Eq. 6 must exist as well:

$\mathrm{M}^{2+}+(\mathrm{C} 2 \mathrm{~S}-\mathrm{H})^{-} \rightleftharpoons \mathrm{M}(\mathrm{C} 2 \mathrm{~S}-\mathrm{H})^{+}$

$K_{\mathrm{M}(\mathrm{C} 2 \mathrm{~S}-\mathrm{H})}^{\mathrm{M}}=\left[\mathrm{M}(\mathrm{C} 2 \mathrm{~S}-\mathrm{H})^{+}\right] /\left(\left[\mathrm{M}^{2+}\right]\left[(\mathrm{C} 2 \mathrm{~S}-\mathrm{H})^{-}\right]\right)$

Consequently, we are dealing here with a cyclic system as shown in the equilibrium scheme in Eq. 7 [38, 47]:

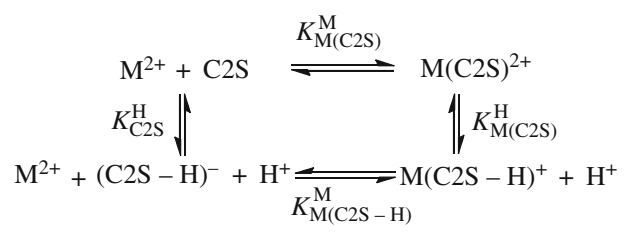

This scheme involves four equilibrium constants and because it is of a cyclic nature only three constants are independent of each other; the size of the fourth constant is automatically determined by the other three as follows from Eqs. 8 and 9:

$\log K_{\mathrm{M}(\mathrm{C} 2 \mathrm{~S})}^{\mathrm{M}}-\mathrm{p} K_{\mathrm{M}(\mathrm{C} 2 \mathrm{~S})}^{\mathrm{H}}=\log K_{\mathrm{M}(\mathrm{C} 2 \mathrm{~S}-\mathrm{H})}^{\mathrm{M}}-\mathrm{p} K_{\mathrm{C} 2 \mathrm{~S}}^{\mathrm{H}}$

$\log K_{\mathrm{M}(\mathrm{C} 2 \mathrm{~S}-\mathrm{H})}^{\mathrm{M}}=\log K_{\mathrm{M}(\mathrm{C} 2 \mathrm{~S})}^{\mathrm{M}}-\mathrm{p} K_{\mathrm{M}(\mathrm{C} 2 \mathrm{~S})}^{\mathrm{H}}+\mathrm{p} K_{\mathrm{C} 2 \mathrm{~S}}^{\mathrm{H}}$

Application of the constants listed in columns 2 and 3 of Table 1 together with $\mathrm{p} K_{\mathrm{C} 2 \mathrm{~S}}^{\mathrm{H}}=12.65 \pm 0.12$ (see "Deprotonation of neutral C2S") affords, based on Eq. 9, the stability constants according to Eq. 6; these values are listed in column 4 of Table 1 . The corresponding distribution curves of the various species in the $\mathrm{pH}$ range $2-8$ are shown in Fig. 3. All the equilibrium constants given in Table 1 need to be discussed in detail; we begin with the acidity constants of the $\mathrm{M}(\mathrm{C} 2 \mathrm{~S})^{2+}$ complexes.

Considerations on the acidity of the $\mathrm{M}(\mathrm{C} 2 \mathrm{~S})^{2+}$ complexes

Of course, one expects that a metal ion coordinated at N3 will facilitate the deprotonation of the exocyclic $(\mathrm{C} 4) \mathrm{NH}_{2}$ 

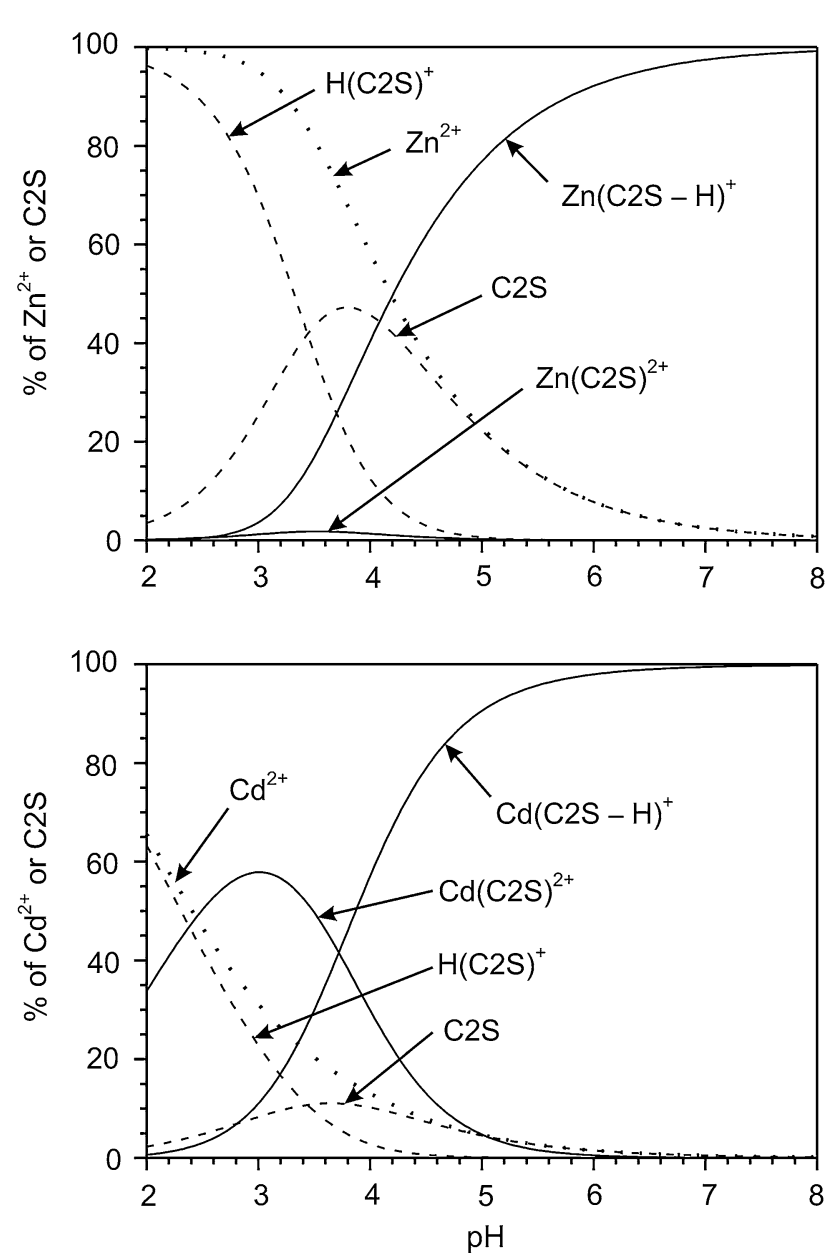

Fig. 3 Effect of $\mathrm{pH}$ on the concentrations of the species present in aqueous solution of the $\mathrm{Zn}^{2+} / \mathrm{C} 2 \mathrm{~S}$ (top) and $\mathrm{Cd}^{2+} / \mathrm{C} 2 \mathrm{~S}$ (bottom) systems. The results are given as the percentages of the total $\mathrm{C} 2 \mathrm{~S}$ or $\mathrm{M}^{2+}$ concentrations which are present in a $1: 1$ ratio $(1 \mathrm{mM})$. The calculations were done with the equilibrium constants listed in Table 1 for a concentration of $10^{-3} \mathrm{M}$ for each reactant $\left(25^{\circ} \mathrm{C} ; I=\right.$ $0.5 \mathrm{M}, \mathrm{KNO}_{3}$ ) (for the concentrations employed in the experiments see "Materials and methods"). The broken lines indicate the free ligand species, the dotted lines free $\mathrm{M}^{2+}$, and the solid lines the metal ion complexes. Note, the possible formation of hydroxo complexes (especially in the case of $\mathrm{Zn}^{2+}$ ) [36] in the uppermost $\mathrm{pH}$ range is not considered in the calculations. Furthermore, the concentration of $(\mathrm{C} 2 \mathrm{~S}-\mathrm{H})^{-}$is not seen in the figure because this species occurs only at high $\mathrm{pH}$, i.e., outside the $\mathrm{pH}$ range shown

group. For example, for $\mathrm{Pt}(\mathrm{II})-\mathrm{am}(\mathrm{m})$ ine complexes a maximum acidification of about $4 \mathrm{p} K$ units has been observed, i.e., from $\mathrm{p} K_{\mathrm{a}}=16.7$ in free 1-methylcytosine [39] to $\mathrm{p} K_{\mathrm{a}} \approx 12.5$ in the complexes [37]. However, the resulting acidifications as defined by Eq. 10 for the present cases are much larger, as follows from the results given in Eqs. 11 and 12:

$\Delta \mathrm{p} K_{\mathrm{a} / \mathrm{M}}=\mathrm{p} K_{\mathrm{C} 2 \mathrm{~S}}^{\mathrm{H}}-\mathrm{p} K_{\mathrm{M}(\mathrm{C} 2 \mathrm{~S})}^{\mathrm{H}}$
$\Delta \mathrm{p} K_{\mathrm{a} / \mathrm{Zn}}=(12.65 \pm 0.12)-(3.35 \pm 0.05)=9.30 \pm 0.13$

$\Delta \mathrm{p} K_{\mathrm{a} / \mathrm{Cd}}=(12.65 \pm 0.12)-(3.09 \pm 0.04)=9.56 \pm 0.13$

Clearly, the absolute size of these observed acidifications amounting to about $9.5 \mathrm{pK}$ units is tremendous and is much larger than the abovementioned maximum $4 \mathrm{pK}$ units for certain $\mathrm{Pt}(\mathrm{II})$ complexes. Indeed, usually divalent metal ions like $\mathrm{Cu}^{2+}, \mathrm{Ni}^{2+}$, and $\mathrm{Pt}^{2+}$ lead (with purines) to acidifications of about $2 \mathrm{pK}$ units only [47, 48]; larger acidifications can be achieved under special conditions, especially if two metal ions become involved [37, 49]. Hence, the question arises: What is special about the $\mathrm{Zn}(\mathrm{C} 2 \mathrm{~S})^{2+}$ and $\mathrm{Cd}(\mathrm{C} 2 \mathrm{~S})^{2+}$ complexes?

From Fig. 2 it follows that the acidity constant as defined in Eq. 3b may be redefined as given in Eq. 13:

$K_{\mathrm{C} 2 \mathrm{~S}}^{\mathrm{H}}=\frac{\left[(\mathrm{C} 2 \mathrm{~S}-\mathrm{H})^{-}\right]\left[\mathrm{H}^{+}\right]}{[\mathrm{C} 2 \mathrm{~S}]}=\frac{\left[(\text { imino }-\mathrm{H})^{-}\right]\left[\mathrm{H}^{+}\right]}{[\text {amino }]+[\text { imino }]}$

In addition, for the tautomeric equilibrium seen in Fig. 2 Eq. 14 holds and for the deprotonation equilibrium of the imino tautomer Eq. 15 holds:

$K_{\mathrm{T}}=[$ imino $] /[$ amino $]$

$K_{\mathrm{a}(\text { imino })}=\left[(\text { imino }-\mathrm{H})^{-}\right]\left[\mathrm{H}^{+}\right] /[$imino $]$

Combination of these three equations leads to Eq. 16:

$K_{\mathrm{a}(\text { imino })}=K_{\mathrm{C} 2 \mathrm{~S}}^{\mathrm{H}}\left(1+\frac{1}{K_{\mathrm{T}}}\right)$

If $K_{\mathrm{T}}$ is getting very large, the tautomeric equilibrium of Fig. 2 is completely on the side of the imino-thiol tautomer and $K_{\mathrm{a} \text { (imino) }}=K_{\mathrm{C} 2 \mathrm{~S}}^{\mathrm{H}}$. However, as concluded in "Deprotonation of neutral C2S," the tautomeric equilibrium considered is far on the side of the amino-thione form, i.e., $K_{\mathrm{T}}$ is small. If one assumes that the intramolecular and dimensionless equilibrium constant $K_{\mathrm{T}}=10^{-4}$, from Eq. 16 it follows that $K_{\mathrm{a} \text { (imino) }}=10^{-8.65}$ and for $K_{\mathrm{T}}=10^{-6}$ it follows that $K_{\mathrm{a} \text { (imino) }}=10^{-6.65}$. Because the metal ion in the $\mathrm{M}(\mathrm{C} 2 \mathrm{~S}-\mathrm{H})^{+}$complexes is certainly thioate-coordinated (see "Conclusions regarding the structure of the $\mathrm{M}(\mathrm{C} 2 \mathrm{~S}-\mathrm{H})^{+}$complexes"), one obtains with the acidity constants in Table 1 (column 3) approximate acidifications of $\Delta \mathrm{p} K_{\mathrm{a}} \approx 5.5-3.5$ - and these values are of a reasonable order.

To conclude, the very large acidifications as expressed in Eqs. 11 and 12 are clearly due to the tautomeric equilibrium between an amino and an imino form (Fig. 2, left) and metal ion coordination to the thioate group of the latter. 
Evaluation of the stability of the $\mathrm{M}(\mathrm{C} 2 \mathrm{~S})^{2+}$ complexes

In the $\mathrm{M}^{2+}$ complexes of $\mathrm{Cyd}, \mathrm{N} 3$ is the primary binding site for metal ions, but depending on the kind of $\mathrm{M}^{2+}$ involved the ortho-amino group, (C4) $\mathrm{NH}_{2}$, may lead to some steric inhibition. In accord with this, the complexes of ortho-amino(methyl)pyridine derivatives $(o \mathrm{PyN})$ are generally less stable than those formed with pyridine-type ligands (PyN) [25, 50]. Similarly, again depending on the kind of metal ion involved, the (C2)O group, neighboring $\mathrm{N} 3$, may give rise to (inner-sphere or outer-sphere) chelates, leading thus to enhanced stabilities of the M(Cyd $)^{2+}$ complexes compared with those of the corresponding $\mathrm{M}(o \mathrm{PyN})^{2+}$ species [25].

In the above context one should recall that for families of structurally related ligands (L), plots of $\log K_{\mathrm{M}(\mathrm{L})}^{\mathrm{M}}$ versus $\mathrm{p} K_{\mathrm{H}(\mathrm{L})}^{\mathrm{H}}$ result in straight lines (Eq. 17) [51]:

$\log K_{\mathrm{M}(\mathrm{L})}^{\mathrm{M}}=m \cdot \mathrm{p} K_{\mathrm{H}(\mathrm{L})}^{\mathrm{H}}+b$

This is also true for the complexes of PyN-type or $o$ PyNtype ligands [50]. For the complexes of $\mathrm{Zn}^{2+}$ or $\mathrm{Cd}^{2+}$ with $o$ PyN-type ligands, the previously established [50] straightline parameters $m$ and $b$ are given in Eqs. 18 and 19:

$\log K_{\mathrm{Zn}(o \mathrm{PyN})}^{\mathrm{Zn}}=0.103 \cdot \mathrm{p} K_{\mathrm{H}(o \mathrm{PyN})}^{\mathrm{H}}-0.398$

$\log K_{\mathrm{Cd}(o \mathrm{PyN})}^{\mathrm{Cd}}=0.131 \cdot \mathrm{p} K_{\mathrm{H}(o \mathrm{PyN})}^{\mathrm{H}}-0.028$

The error limits of the log stability constants calculated with given $\mathrm{p} K_{\mathrm{H}(o \mathrm{PyN})}^{\mathrm{H}}$ values and Eqs. 18 and 19 amount to \pm 0.08 and $\pm 0.09(3 \sigma) \log$ units, respectively, in the $\mathrm{p} K_{\mathrm{a}}$ range of about 3-7.5 [50].

The reference lines as defined by Eqs. 18 and 19 are seen in Fig. 4 together with the $\log K_{\mathrm{M}(\mathrm{PyN})}^{\mathrm{M}}$ versus $\mathrm{p} K_{\mathrm{H}(\mathrm{PyN})}^{\mathrm{H}}$ plots, showing that an ortho-amino group leads to some steric hindrance in the $\mathrm{Zn}^{2+}$ and $\mathrm{Cd}^{2+}$ complexes. However, as the position of the data points for the $\mathrm{Zn}(\mathrm{Cyd})^{2+}$ and $\mathrm{Cd}(\mathrm{Cyd})^{2+}$ complexes above the $o$ PyN reference lines proves, this inhibition is partially offset by an interaction with the (C2)O group [25]. Much more important for the present is that the stabilities of the $\mathrm{Zn}(\mathrm{C} 2 \mathrm{~S})^{2+}$ and $\mathrm{Cd}(\mathrm{C} 2 \mathrm{~S})^{2+}$ complexes are significantly above the reference lines. This shows that the thiocytosine residue compared with the parent cytosine residue has a much higher affinity toward the two metal ions considered. In addition, the fact that the stability of the $\mathrm{Cd}^{2+}$ complex is even more enhanced than that of the $\mathrm{Zn}^{2+}$ complex is in accord with the larger thiophilicity of $\mathrm{Cd}^{2+}$ compared with that of $\mathrm{Zn}^{2+}$ $[52,53]$, and thus this observation demonstrates further the importance of $(\mathrm{C} 2) \mathrm{S}$ for metal ion binding.

The stability enhancements indicated can be quantified with Eq. 20:

$\log \Delta_{\mathrm{M} / \mathrm{C} 2 \mathrm{~S}}=\log K_{\mathrm{M}(\mathrm{C} 2 \mathrm{~S})}^{\mathrm{M}}-\log K_{\mathrm{M}(\mathrm{C} 2 \mathrm{~S}) \text { calc }}^{\mathrm{M}}$
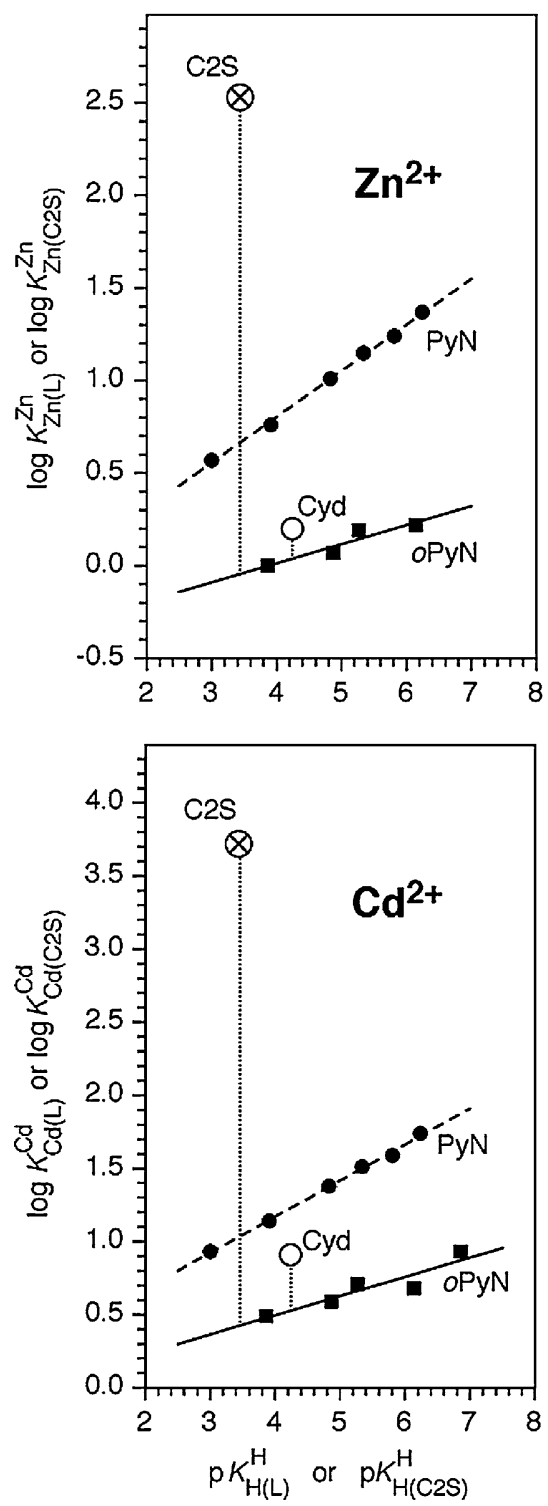

Fig. 4 Evidence for an increased stability of the $\mathrm{M}(\mathrm{C} 2 \mathrm{~S})^{2+}$ complexes of $\mathrm{Zn}^{2+}$ and $\mathrm{Cd}^{2+}(\otimes)$ based on the comparison of their data points (values from Table $1 ; 25{ }^{\circ} \mathrm{C} ; I=0.5 \mathrm{M}, \mathrm{KNO}_{3}$ ) with the $\log$ $K_{\mathrm{M}(\mathrm{L})}^{\mathrm{M}}$ versus $\mathrm{p} K_{\mathrm{H}(\mathrm{L})}^{\mathrm{H}}$ straight-line relationships for simple pyridinetype ligands $\mathrm{PyN}(\boldsymbol{O})$ and the sterically inhibited orthoamino(methyl)pyridine-type ligands $o \mathrm{PyN}(\boldsymbol{\square})$ [48]; the data points for the $\mathrm{M}^{2+} /$ Cyd systems $(\bigcirc)$ [25] are given for further comparisons $\left(25^{\circ} \mathrm{C} ; I=0.5 \mathrm{M}, \mathrm{NaNO}_{3}\right)$. The least-squares straight reference lines are drawn according to Eq. 17. The plotted equilibrium constants refer (from left to right) for the PyN systems (L) (O) to 3-chloropyridine, 4-bromopyridine, 4-(chloromethyl)pyridine, pyridine, 3-methylpyridine, and 3,5-dimethylpyridine [50], and for the ortho-substituted $o$ PyN systems (L) (ם) to 2-methyl-5-bromopyridine, 2-amino-5bromopyridine, tubercidin (7-deazaadenosine), 2-methylpyridine, and 2-aminopyridine (2APy) (Eqs. 18, 19); the stability constant of $\mathrm{Zn}(2 \mathrm{APy})^{2+}$ was not used because of its large error [48], which is due to hydrolysis $\left(25^{\circ} \mathrm{C} ; I=0.5 \mathrm{M}, \mathrm{NaNO}_{3}\right)$ [50]. The reduced stability of the $\mathrm{M}(o \mathrm{PyN})^{2+}$ complexes, compared with that of the $\mathrm{M}(\mathrm{PyN})^{2+}$ ones, reflects the steric inhibition of an ortho-amino (or ortho-methyl) group. The vertical dotted lines represent the stability enhancements as defined by Eq. 20 
Table 2 Stability constant comparisons for the $\mathrm{Zn}(\mathrm{C} 2 \mathrm{~S})^{2+}$ and $\mathrm{Cd}(\mathrm{C} 2 \mathrm{~S})^{2+}$ complexes between the measured stability constants (Eq. 4) and the calculated ones together with the resulting stability differences $\log \Delta_{\mathrm{M} / \mathrm{C} 2 \mathrm{~S}}$ as defined by Eq. 20. For the $\mathrm{Zn}(\mathrm{Cyd})^{2+}$ and $\mathrm{Cd}(\mathrm{Cyd})^{2+}$ complexes the analogous data [25] are listed for comparison (aqueous solution; $25^{\circ} \mathrm{C} ; I=0.5 \mathrm{M}$ )

\begin{tabular}{lllrl}
\hline $\mathrm{M}^{2+}$ & $\mathrm{L}$ & $\log K_{\mathrm{M}(\mathrm{L})}^{\mathrm{M}}$ & \multicolumn{1}{c}{$\log K_{\mathrm{M}(\mathrm{L}) o p}^{\mathrm{M}}$} & \multicolumn{1}{l}{$\log \Delta_{\mathrm{M} / \mathrm{L}}$} \\
\hline $\mathrm{Zn}^{2+}$ & $\mathrm{C} 2 \mathrm{~S}$ & $2.53 \pm 0.04^{\mathrm{a}}$ & $-0.04 \pm 0.08^{\mathrm{b}}$ & $2.57 \pm 0.09$ \\
$\mathrm{Cd}^{2+}$ & $\mathrm{C} 2 \mathrm{~S}$ & $3.72 \pm 0.03^{\mathrm{a}}$ & $0.42 \pm 0.09^{\mathrm{b}}$ & $3.30 \pm 0.09$ \\
$\mathrm{Zn}^{2+}$ & $\mathrm{Cyd}$ & $0.20 \pm 0.11$ & $0.04 \pm 0.08$ & $0.16 \pm 0.14$ \\
$\mathrm{Cd}^{2+}$ & Cyd & $0.91 \pm 0.07$ & $0.53 \pm 0.09$ & $0.38 \pm 0.11$
\end{tabular}

Cyd cytidine (see Fig. 1)

${ }^{\text {a }}$ From column 2 in Table 1

${ }^{\mathrm{b}}$ Calculated with $\mathrm{p} K_{\mathrm{H}(\mathrm{C} 2 \mathrm{~S})}^{\mathrm{H}}=3.44$ (Table 1 ) for a coordination of $\mathrm{M}^{2+}$ to a simple ortho-aminopyridine-type ligand according to the straightline Eqs. 18 and 19

The first stability constant given on the right-hand side of Eq. 20 is the one experimentally measured for the $\mathrm{M}(\mathrm{C} 2 \mathrm{~S})^{2+}$ complexes. The second stability constant is calculated on the basis of Eqs. 18 and 19 by application of the acidity constant $\mathrm{p} K_{\mathrm{H}(\mathrm{C} 2 \mathrm{~S})}^{\mathrm{H}}=3.44$ (Table 1). The corresponding results are summarized in Table 2, together with those for the $\mathrm{M}(\mathrm{Cyd})^{2+}$ complexes taken from earlier work [25].

Conclusions regarding the structure of the $\mathrm{M}(\mathrm{C} 2 \mathrm{~S})^{2+}$ complexes

The stability enhancements for the $\mathrm{M}(\mathrm{C} 2 \mathrm{~S})^{2+}$ complexes (Table 2, column 5) indicate $[51,52]$ that chelate formation occurs and that open (op) species are in equilibrium with closed (cl) ones, i.e., that the intramolecular equilibrium in Eq. 21 operates:

$\mathrm{M}(\mathrm{C} 2 \mathrm{~S})_{\mathrm{op}}^{2+} \rightleftharpoons \mathrm{M}(\mathrm{C} 2 \mathrm{~S})_{\mathrm{cl}}^{2+}$

However, there is a problem here: which is the primary binding site in these complexes? For the $\mathrm{M}(\mathrm{Cyd})^{2+}$ complexes it is $\mathrm{N} 3$; however, in the case of the $\mathrm{M}(\mathrm{C} 2 \mathrm{~S})^{2+}$ complexes the stability enhancements are much larger (Table 2, column 5) than the $\mathrm{M}^{2+}$ affinities of the N3 site,

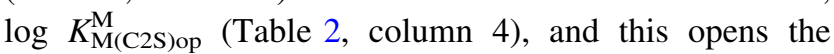
possibility that $\mathrm{M}^{2+}$ is coordinated in a monodentate fashion also to the sulfur atom at $\mathrm{C} 2$. This means that there is the possibility for two open isomers; one with $\mathrm{M}^{2+}$ at N3 and one with $\mathrm{M}^{2+}$ at $(\mathrm{C} 2) \mathrm{S}$; these species are designated as $(\mathrm{M} \cdot \mathrm{N} 3 / \mathrm{C} 2 \mathrm{~S})_{\mathrm{op}}^{2+}$ and $(\mathrm{N} 3 / \mathrm{C} 2 \mathrm{~S} \cdot \mathrm{M})_{\mathrm{op}}^{2+}$, respectively. Because the stability of the open $(\mathrm{N} 3 / \mathrm{C} 2 \mathrm{~S} \cdot \mathrm{M})_{\mathrm{op}}^{2+}$ isomer is not known, it is not possible to calculate the formation degree of the chelated species.

However, as far as the extent of (C2)S- $\mathrm{M}^{2+}$ binding is concerned, some conclusions are possible. The following reasoning is closely related to a new evaluation method which was recently introduced to quantify the chelate [54] or macrochelate [55] effect. Considering that for principal reasons two open isomers occur in solution, (M.N3/C2S $)_{\text {op }}^{2+}$ and $(\mathrm{N} 3 / \mathrm{C} 2 \mathrm{~S} \cdot \mathrm{M})_{\mathrm{op}}^{2+}$, as indicated above, as well as the chelated, or closed species, $\mathrm{M}(\mathrm{C} 2 \mathrm{~S})_{\mathrm{cl}}^{2+}$, Eq. $4 \mathrm{~b}$ may be rewritten as given in Eq. 22:

$$
\begin{aligned}
K_{\mathrm{M}(\mathrm{C} 2 \mathrm{~S})}^{\mathrm{M}} & =\frac{\left[\mathrm{M}(\mathrm{C} 2 \mathrm{~S})^{2+}\right]}{\left[\mathrm{M}^{2+}\right][\mathrm{C} 2 \mathrm{~S}]} \\
& =\frac{\left[(\mathrm{M} \cdot \mathrm{N} 3 / \mathrm{C} 2 \mathrm{~S})_{\mathrm{op}}^{2+}\right]+\left[\left(\mathrm{N} 3 / \mathrm{C} 2 \mathrm{~S} \cdot \mathrm{M}_{\mathrm{op}}^{2+}\right]+\left[\mathrm{M}(\mathrm{C} 2 \mathrm{~S})_{\mathrm{cl}}^{2+}\right]\right.}{\left[\mathrm{M}^{2+}\right][\mathrm{C} 2 \mathrm{~S}]} \\
& =k_{(\mathrm{M} \cdot \mathrm{N} 3 / \mathrm{C} 2 \mathrm{~S}) \mathrm{op}}^{\mathrm{M}}+k_{(\mathrm{N} 3 / \mathrm{C} 2 \mathrm{~S} \cdot \mathrm{M}) \mathrm{op}}^{\mathrm{M}}+k_{\mathrm{M}(\mathrm{C} 2 \mathrm{~S}) \mathrm{cl}}^{\mathrm{M}}
\end{aligned}
$$

The micro stability constants given on the right side in Eq. 22b quantify the formation of the individual isomers; as far as $\mathrm{M}(\mathrm{C} 2 \mathrm{~S})_{\mathrm{cl}}^{2+}$ is concerned, it does of course not matter if chelate formation starts from the $(\mathrm{C} 2) \mathrm{S}$-bound or the N3bound $\mathrm{M}^{2+}$; the resulting chelates always have the same structure(s) (see later).

From the four constants which appear in Eq. 22b only values for $K_{\mathrm{M}(\mathrm{C} 2 \mathrm{~S})}^{\mathrm{M}}$ and $k_{(\mathrm{M} \cdot \mathrm{N} 3 / \mathrm{C} 2 \mathrm{~S}) \text { op }}^{\mathrm{M}}$ are known; the first one was measured (Table 1) and the second one can be calculated with $\mathrm{p} K_{\mathrm{H}(\mathrm{C} 2 \mathrm{~S})}^{\mathrm{H}}=3.44$ and the straight lines defined by Eqs. 18 and 19. If we concentrate for the moment on the $\mathrm{Cd}(\mathrm{C} 2 \mathrm{~S})^{2+}$ system, we obtain, based on Eqs. 22b, Eq. 23:

$k_{(\mathrm{N} 3 / \mathrm{C} 2 \mathrm{~S} \cdot \mathrm{Cd}) \text { op }}^{\mathrm{Cd}}+k_{\mathrm{Cd}(\mathrm{C} 2 \mathrm{~S}) \mathrm{cl}}^{\mathrm{Cd}}=K_{\mathrm{Cd}(\mathrm{C} 2 \mathrm{~S})}^{\mathrm{Cd}}-k_{(\mathrm{Cd} \cdot \mathrm{N} 3 / \mathrm{C} 2 \mathrm{~S}) \text { op }}^{\mathrm{Cd}}$

$$
=10^{3.72}-10^{0.42} \approx 10^{3.72}
$$

The lesson from Eq. 23 is that $\mathrm{N} 3-\mathrm{Cd}^{2+}$ binding contributes very little to the stability of the $\mathrm{Cd}(\mathrm{C} 2 \mathrm{~S})^{2+}$ complexes; in other words, the stability of these species is overwhelmingly given by the $(\mathrm{C} 2) \mathrm{S}-\mathrm{Cd}^{2+}$ interaction, which determines solely the stability of $(\mathrm{N} 3 / \mathrm{C} 2 \mathrm{~S} \cdot \mathrm{Cd})_{\mathrm{op}}^{2+}$ and consequently also to the very largest part that of $\mathrm{Cd}(\mathrm{C} 2 \mathrm{~S})_{\mathrm{cl}}^{2+}$.

From the $\mathrm{Cd}(\mathrm{Cyd})^{2+}$ species about $58 \%$ exist in the form of chelates [25] and this formation degree corresponds to a stability enhancement of $\log \Delta_{\mathrm{Cd} / \mathrm{Cyd}}=0.38$ [25]. If we assume that $\mathrm{Cd}(\mathrm{C} 2 \mathrm{~S})_{\mathrm{cl}}^{2+}$ reaches the same formation degree, the difference $\log k_{\mathrm{Cd}(\mathrm{C} 2 \mathrm{~S}) \mathrm{cl}}^{\mathrm{Cd}}-\log k_{(\mathrm{N} 3 / \mathrm{C} 2 \mathrm{~S} \cdot \mathrm{Cd}) o p}^{\mathrm{Cd}}$ must amount to $0.38 \log$ units and we can then rewrite Eq. $22 \mathrm{~b}$ for the $\mathrm{Cd}^{2+}$ case as follows:

$K_{\mathrm{Cd}(\mathrm{C} 2 \mathrm{~S})}^{\mathrm{Cd}}=k_{(\mathrm{Cd} \cdot \mathrm{N} 3 / \mathrm{C} 2 \mathrm{~S}) \mathrm{op}}^{\mathrm{Cd}}+k_{(\mathrm{N} 3 / \mathrm{C} 2 \mathrm{~S} \cdot \mathrm{Cd}) \mathrm{op}}^{\mathrm{Cd}}+k_{\mathrm{Cd}(\mathrm{C} 2 \mathrm{~S}) \mathrm{cl}}^{\mathrm{Cd}}$

$10^{3.72}=10^{0.42}+10^{3.19}+10^{3.57} \approx 10^{3.72}$

From $K_{\mathrm{I} / \mathrm{Cd}}=10^{\log \Delta}-1=10^{(3.57-3.19)}-1=10^{0.38}-1=$ 1.40 follows [51, 52] a formation degree of $58 \%$ for the chelate (see Eq. 21) as it should be in accord with the initial assumption. However, for the remaining $42 \%$, which 
exist as the open species, (N3/C2S.Cd) $)_{\mathrm{op}}^{2+}$ and $(\mathrm{Cd} \cdot \mathrm{N} 3 /$ $\mathrm{C} 2 \mathrm{~S})_{\mathrm{op}}^{2+}$, we learn, based on Eq. 25 ,

$\frac{k_{(\mathrm{N} 3 / \mathrm{C} 2 \mathrm{~S} \cdot \mathrm{Cd}) \text { op }}^{\mathrm{Cd}}}{k_{(\mathrm{Cd} \cdot \mathrm{N} 3 / \mathrm{C} 2 \mathrm{~S})_{\mathrm{op}}}^{\mathrm{Cd}}}=\frac{\left[(\mathrm{N} 3 / \mathrm{C} 2 \mathrm{~S} \cdot \mathrm{Cd})_{\mathrm{op}}^{2+}\right]}{\left[(\mathrm{Cd} \cdot \mathrm{N} 3 / \mathrm{C} 2 \mathrm{~S})_{\mathrm{op}}^{2+}\right]}=\frac{10^{3.19}}{10^{0.42}}=\frac{10^{2.77}}{1}$

$$
=\frac{589}{1}=\frac{99.83 \%}{0.17 \%}
$$

that $41.93 \%$ occur in the $(\mathrm{C} 2) \mathrm{S}$-bonded form $(\mathrm{N} 3 / \mathrm{C} 2 \mathrm{~S} \cdot \mathrm{Cd})_{\mathrm{op}}^{2+}$ and only $0.07 \%$ in the (N3)-bonded form. To say it differently, the $\mathrm{Cd}(\mathrm{C} 2 \mathrm{~S})_{\mathrm{cl}}^{2+}$ and $(\mathrm{N} 3 / \mathrm{C} 2 \mathrm{~S} \cdot \mathrm{Cd})_{\mathrm{op}}^{2+}$ species dominate the system very strongly (more than 99.9\%) and the (N3)-bonded form, $(\mathrm{Cd} \cdot \mathrm{N} 3 / \mathrm{C} 2 \mathrm{~S})_{\mathrm{op}}^{2+}$, occurs only in traces.

If one carries out the same evaluation for the $\mathrm{Zn}(\mathrm{C} 2 \mathrm{~S})^{2+}$ system based on $31 \% \mathrm{Zn}(\mathrm{Cyd})_{\mathrm{cl}}^{2+}$, corresponding to $\log \Delta_{\mathrm{Zn} /}$ Cyd $=0.16$ [25], one obtains the following equations:

$K_{\mathrm{Zn}(\mathrm{C} 2 \mathrm{~S})}^{\mathrm{Zn}}=k_{(\mathrm{Zn} \cdot \mathrm{N} 3 / \mathrm{C} 2 \mathrm{~S}) \mathrm{op}}^{\mathrm{Zn}}+k_{(\mathrm{N} 3 / \mathrm{C} 2 \mathrm{~S} \cdot \mathrm{Zn}) \mathrm{op}}^{\mathrm{Zn}}+k_{\mathrm{Zn}(\mathrm{C} 2 \mathrm{~S}) \mathrm{cl}}^{\mathrm{Zn}}$

$10^{2.53}=10^{-0.04}+10^{2.14}+10^{2.30} \approx 10^{2.53}$

$\frac{k_{(\mathrm{N} 3 / \mathrm{C} 2 \mathrm{~S} \cdot \mathrm{Zn}) \mathrm{op}}^{\mathrm{Zn}}}{k_{(\mathrm{Zn} \cdot \mathrm{N} 3 / \mathrm{C} 2 \mathrm{~S})_{\mathrm{op}}}^{\mathrm{Z}}}=\frac{\left[(\mathrm{N} 3 / \mathrm{C} 2 \mathrm{~S} \cdot \mathrm{Zn})_{\mathrm{op}}^{2+}\right]}{\left[(\mathrm{Zn} \cdot \mathrm{N} 3 / \mathrm{C} 2 \mathrm{~S})_{\mathrm{op}}^{2+}\right]}=\frac{10^{2.14}}{10^{-0.04}}=\frac{10^{2.18}}{1}$

$$
=\frac{151.4}{1}=\frac{99.34 \%}{0.66 \%}
$$

Hence, $31 \%$ of the species are present in the chelated form, $\mathrm{Zn}(\mathrm{C} 2 \mathrm{~S})_{\mathrm{cl}}^{2+}$, and $69 \%$ in the two open forms, which occur to $68.5 \%$ as $(\mathrm{N} 3 / \mathrm{C} 2 \mathrm{~S} \cdot \mathrm{Zn})_{\mathrm{op}}^{2+}$ and $0.5 \%$ as $(\mathrm{Zn} \cdot \mathrm{N} 3 / \mathrm{C} 2 \mathrm{~S})_{\mathrm{op}}^{2+}$. Again we note that $(\mathrm{C} 2) \mathrm{S}-\mathrm{Zn}^{2+}$ coordination is strongly dominating (in total to $99.5 \%$ ).

To conclude, from the above evaluations it follows unequivocally that the $(\mathrm{C} 2) \mathrm{S}-\mathrm{M}^{2+}$ interaction is the stability-determining factor of the $\mathrm{M}(\mathrm{C} 2 \mathrm{~S})^{2+}$ complexes with $\mathrm{Zn}^{2+}$ and $\mathrm{Cd}^{2+}$ and that purely (N3)-coordinated species occur only in trace amounts. What remains uncertain is the exact extent of chelate formation. However, one may postulate with confidence that the formation degrees of chelates for $\mathrm{Zn}(\mathrm{Cyd})_{\mathrm{cl}}^{2+}$ and $\mathrm{Cd}(\mathrm{Cyd})_{\mathrm{cl}}^{2+}$, which amount to about 31 and $58 \%$, respectively [25], are lower limits for the formation degrees of the $\mathrm{Zn}(\mathrm{C} 2 \mathrm{~S})_{\mathrm{cl}}^{2+}$ and $\mathrm{Cd}(\mathrm{C} 2 \mathrm{~S})_{\mathrm{cl}}^{2+}$ chelates. In fact, the formation degrees of the $\mathrm{M}(\mathrm{C} 2 \mathrm{~S})_{\mathrm{cl}}^{2+}$ species are most likely significantly larger than those of $\mathrm{M}(\mathrm{Cyd})_{\mathrm{cl}}^{2+}$ because the steric constraints are lower owing to the larger size of sulfur compared with that of oxygen. In the solid state the formation of (distorted) four-membered rings with $\mathrm{Cd}^{2+}[18,56]$ and $\mathrm{Zn}^{2+}[57]$ involving $\mathrm{N} 3$ and $(\mathrm{C} 2) \mathrm{O}$ of cytosine residues are known [25]. The corresponding structures may be surmised for the complexes with C2S and, in fact, it is known that low-membered chelates are more easily formed if a (C)O group is replaced by a (C)S site [1]. Furthermore, it may be expected that these fourmembered chelates persist to some extent also in aqueous solution (Fig. 5a). Of course, there is the possibility that also semichelates form with a water molecule between the sulfur-coordinated $\mathrm{M}^{2+}$ and N3 (Fig. 5b). Structures as indicated in Fig. 5c involving a sulfur-hydrogen bond are in aqueous solution not expected to be important because sulfur is not an excellent site for hydrogen-bond formation under such conditions. Similarly, the structure shown in Fig. 5d, which contains an unstable tautomer of C2S [16, 41], is not expected to reach a significant formation degree, though on the way to the formation of the $\mathrm{M}(\mathrm{C} 2 \mathrm{~S}-\mathrm{H})^{+}$ complexes this species might play a role as an intermediate. To conclude, the structures shown in Fig. $5 \mathrm{c}$ and d, if formed at all, are certainly minority species.

Considerations on the stability of the $\mathrm{M}(\mathrm{C} 2 \mathrm{~S}-\mathrm{H})^{+}$ complexes

As indicated above, the deprotonation of the $(\mathrm{C} 4) \mathrm{NH}_{2}$ group in the $\mathrm{M}(\mathrm{C} 2 \mathrm{~S})^{2+}$ complexes might proceed via the intermediate shown in Fig. 5d and this could then lead to the four-membered chelate shown in Fig. 7a (vide infra) with the negative charge mainly located at N3. Even though this structure is rather unlikely as will be concluded later and as already indicated in "Deprotonation of neutral C2S" in the context of Fig. 2, it offers the possibility to evaluate the stability of the $\mathrm{M}(\mathrm{C} 2 \mathrm{~S}-\mathrm{H})^{+}$complexes (Table 1, column 4) somewhat more in detail and to confirm the
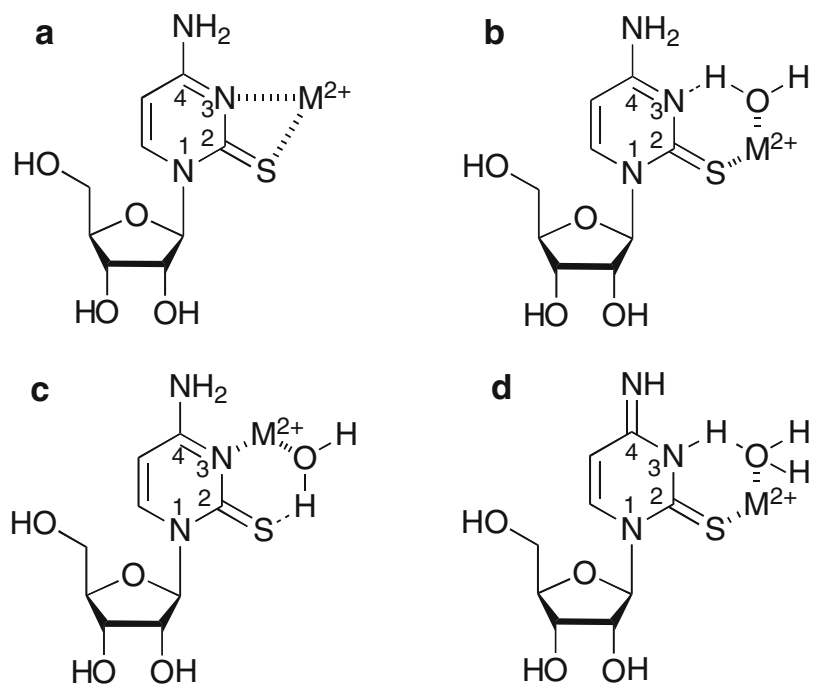

Fig. 5 Possible metal ion binding modes in the chelates formed in equilibrium by the $\mathrm{M}(\mathrm{C} 2 \mathrm{~S})^{2+}$ complexes in aqueous solution. The structures in $\mathbf{c}$ and $\mathbf{d}$ have a low probability for formation. For details see the last paragraph of "Conclusions regarding the structure of the $\mathrm{M}(\mathrm{C} 2 \mathrm{~S})^{2+}$ complexes" 
surmised conclusion. The reason is that for a series of $\mathrm{M}^{2+}$ complexes of uridinate derivatives, $(\mathrm{U}-\mathrm{H})^{-}$, where the negative charge is mainly located at $\mathrm{N} 3$, the straight lines for $\log K_{\mathrm{M}(\mathrm{U}-\mathrm{H})}^{\mathrm{M}}$ versus $\mathrm{p} K_{\mathrm{U}}^{\mathrm{H}}$ plots have been defined (see Eq. 17); the corresponding straight-line parameters for the $\mathrm{Zn}^{2+}$ and $\mathrm{Cd}^{2+}$ systems are given in Eqs. 28 and 29 [58]:

$\log K_{\mathrm{Zn}(\mathrm{U}-\mathrm{H})}^{\mathrm{Zn}}=(0.427 \pm 0.047) \mathrm{p} K_{\mathrm{U}}^{\mathrm{H}}-(1.516 \pm 0.389)$

$\log K_{\mathrm{Cd}(\mathrm{U}-\mathrm{H})}^{\mathrm{Cd}}=(0.388 \pm 0.024) \mathrm{p} K_{\mathrm{U}}^{\mathrm{H}}-(0.354 \pm 0.209)$

The error limits of the $\log$ stability constants calculated with $\mathrm{p} K_{\mathrm{U}}^{\mathrm{H}}$ values and Eqs. 28 and 29 are 0.07 and $0.05(3 \sigma)$ $\log$ units, respectively, in the $\mathrm{p} K_{\mathrm{a}}$ range of about 7-10 [58]; outside this range the error of the intercept $b$ needs to be taken into account as well (see footnote $\mathrm{c}$ in Table 3).

The straight lines defined by Eqs. 28 and 29 are shown in Fig. 6 together with the data points for the $\mathrm{Zn}(\mathrm{C} 2 \mathrm{~S}-\mathrm{H})^{+}$ and $\mathrm{Cd}(\mathrm{C} 2 \mathrm{~S}-\mathrm{H})^{+}$complexes. The stability enhancements are evidently tremendous; they may be defined by Eq. 30 (which is analogous to Eq. 20):

$$
\begin{aligned}
\log \Delta_{\mathrm{M} /(\mathrm{C} 2 \mathrm{~S}-\mathrm{H})} & =\log K_{\mathrm{M}(\mathrm{C} 2 \mathrm{~S}-\mathrm{H})}^{\mathrm{M}}-\log K_{\mathrm{M}(\mathrm{U}-\mathrm{H}) \text { calc }}^{\mathrm{M}} \\
& =\log K_{\mathrm{M}(\mathrm{C} 2 \mathrm{~S}-\mathrm{H})}^{\mathrm{M})}-\log K_{\mathrm{M}(\mathrm{C} 2 \mathrm{~S}-\mathrm{H}) \text { calc }}^{\mathrm{M}}
\end{aligned}
$$

It may be noted that because $\log K_{\mathrm{M}(\mathrm{U}-\mathrm{H}) \text { calc }}^{\mathrm{M}}$ is set equal to $\log K_{\mathrm{M}(\mathrm{C} 2 \mathrm{~S}-\mathrm{H}) \text { calc }}^{\mathrm{M}}$ the stability difference $\log \Delta_{\mathrm{M} /(\mathrm{C} 2 \mathrm{~S}-\mathrm{H})}$

Table 3 Stability constant comparisons for the $\mathrm{Zn}(\mathrm{C} 2 \mathrm{~S}-\mathrm{H})^{+}$and $\mathrm{Cd}(\mathrm{C} 2 \mathrm{~S}-\mathrm{H})^{+}$complexes between the measured stability constants (Eqs. 6,9) and the calculated ones together with the resulting stability differences $\log \Delta_{\mathrm{M} /(\mathrm{C} 2 \mathrm{~S}-\mathrm{H})}$ as defined by Eq. 30. For the $\mathrm{Cd}(\mathrm{U} 2 \mathrm{~S}-\mathrm{H})^{+}$ complex (Fig. 1) the analogous data [3] are listed for comparison (aqueous solution; $25^{\circ} \mathrm{C} ; I=0.5 \mathrm{M}$ )

\begin{tabular}{llccc}
\hline $\mathrm{M}^{2+}$ & $(\mathrm{L}-\mathrm{H})^{-}$ & $\log K_{\mathrm{M}(\mathrm{L}-\mathrm{H})}^{\mathrm{M}}$ & $\log K_{\mathrm{M}(\mathrm{L}-\mathrm{H}) \mathrm{op}}^{\mathrm{M}}$ & $\log \Delta_{\mathrm{M} / \mathrm{L}-\mathrm{H})}$ \\
\hline $\mathrm{Zn}^{2+}$ & $(\mathrm{C} 2 \mathrm{~S}-\mathrm{H})^{-}$ & $11.83 \pm 0.14^{\mathrm{a}}$ & $3.89 \pm 0.47^{\mathrm{b}, \mathrm{c}}$ & $7.9 \pm 0.5$ \\
$\mathrm{Cd}^{2+}$ & $(\mathrm{C} 2 \mathrm{~S}-\mathrm{H})^{-}$ & $13.28 \pm 0.13^{\mathrm{a}}$ & $4.55 \pm 0.25^{\mathrm{b}, \mathrm{c}}$ & $8.7 \pm 0.3$ \\
$\mathrm{Cd}^{2+}$ & $(\mathrm{U} 2 \mathrm{~S}-\mathrm{H})^{-}$ & $4.11 \pm 0.03$ & $2.77 \pm 0.05$ & $1.34 \pm 0.06$ \\
\hline
\end{tabular}

U2S 2-thiouridine (see Fig. 1)

${ }^{\text {a }}$ From column 4 in Table 1

${ }^{\mathrm{b}}$ Calculated with $\mathrm{p} K_{\mathrm{C} 2 \mathrm{~S}}^{\mathrm{H}}=12.65$ (Table 1) for the coordination of $\mathrm{M}^{2+}$ to a uridinate derivative $(\mathrm{U}-\mathrm{H})^{-}$, where the negative charge is mainly located at N3, according to the straight-line Eqs. 28 and 29

c The error limits were calculated as explained for the $\mathrm{Zn}^{2+}$ system as follows: the distance between the lowest data point $\left(\mathrm{p} K_{\mathrm{a}}=7.55\right.$; see Fig. 6) and the intercept $b$ with the $y$-axis is $7.55 \mathrm{p} K$ units; the distance between the highest data point $\left(\mathrm{p} K_{\mathrm{a}}=9.67\right)$ and $\mathrm{p} K_{\mathrm{C} 2 \mathrm{~S}}^{\mathrm{H}}=12.65$ (extrapolation) used for the calculations amounts to $3.0 \mathrm{p} K$ units. Hence, \pm 0.389 ( $=b$; see Eq. 28 ) divided by 7.55 and multiplied by 3.0 gives $\pm 0.155(1 \sigma)$ or $\pm 0.465(3 \sigma)$. By taking further into account the (internal) error limit of \pm 0.07 ( $3 \sigma$; see the text), one obtains according to the error propagation after Gauss $\pm 0.47(3 \sigma) \log$ units, the value given in the table
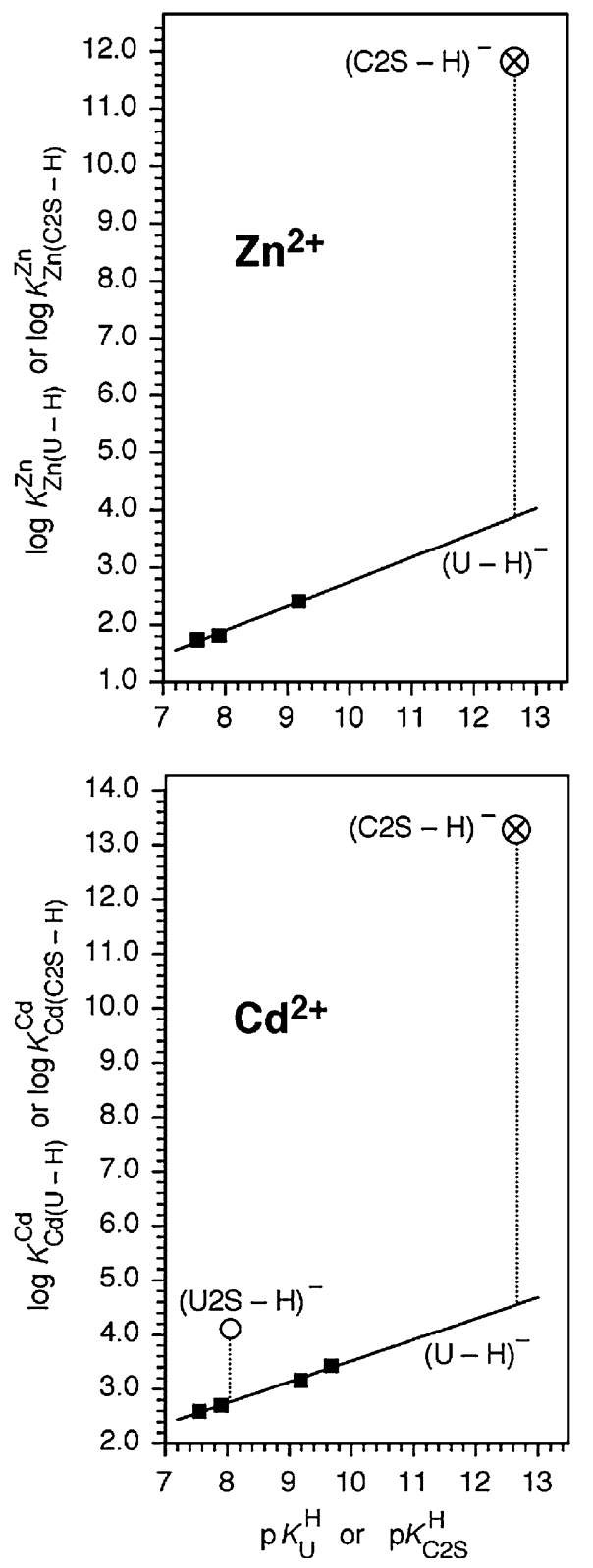

Fig. 6 Evidence of an increased stability of the $\mathrm{M}(\mathrm{C} 2 \mathrm{~S}-\mathrm{H})^{+}$ complexes of $\mathrm{Zn}^{2+}$ and $\mathrm{Cd}^{2+}(\otimes)$ based on the comparison of their data points (values from Table $1 ; 25{ }^{\circ} \mathrm{C} ; I=0.5 \mathrm{M}, \mathrm{KNO}_{3}$ ) with the $\log K_{\mathrm{M}(\mathrm{U}-\mathrm{H})}^{\mathrm{M}}$ versus $\mathrm{p} K_{\mathrm{U}}^{\mathrm{H}}$ straight-line relationships (ם) [58] for uridinate-type ligands $(\mathrm{U}-\mathrm{H})^{-}$and their complexes formed with $\mathrm{Zn}^{2+}$ and $\mathrm{Cd}^{2+}$. The data point for the $\mathrm{Cd}(\mathrm{U} 2 \mathrm{~S}-\mathrm{H})^{+}$complex $(\mathrm{O})[3]$ is given for further comparison $\left(25^{\circ} \mathrm{C} ; I=0.5 \mathrm{M}, \mathrm{NaNO}_{3}\right)$. The leastsquares straight reference lines are drawn according to Eqs. 28 and 29. The plotted equilibrium constants refer to the $\mathrm{M}^{2+} /(\mathrm{U}-\mathrm{H})^{-}$ systems (ם) with (from left to right) 5-fluorouridine, 5-chloro-2'deoxyuridine, uridine, and thymidine ( $2^{\prime}$-deoxy-5-methyluridine) $(25$ ${ }^{\circ} \mathrm{C} ; I=0.1 \mathrm{M}, \mathrm{NaNO}_{3}$ ) [58] (the complex of the last-mentioned ligand with $\mathrm{Zn}^{2+}$ could not be studied owing to hydrolysis [58]). The vertical dotted lines represent the stability enhancements as defined by Eq. 30 . The change in $I$ from 0.1 to $0.5 \mathrm{M}$ is of no significance because the small connected shifts in $\log K$ and $\mathrm{p} K_{\mathrm{a}}$ are "parallel" to each other; moreover, the stability differences considered are very large and far outside of any error limits 
may actually be a bit too small because the possible steric inhibition of $(\mathrm{C} 4) \mathrm{NH}$ [in $(\mathrm{C} 2 \mathrm{~S}-\mathrm{H})^{-}$] compared with that of $(\mathrm{C} 4) \mathrm{O}$ [in $(\mathrm{U}-\mathrm{H})^{-}$] is not accounted for. However, considering the size of the $\log \Delta_{\mathrm{M} /(\mathrm{C} 2 \mathrm{~S}-\mathrm{H})}$ values this effect is clearly negligible. Of course, the first stability constant on the right side of Eq. 30 is the measured one (Table 1, column 4) and the second stability constant is calculated with $\mathrm{p} K_{\mathrm{C} 2 \mathrm{~S}}^{\mathrm{H}}=12.65$ and Eqs. 28 and 29; the results are listed in Table 3 together with the data obtained earlier for $\mathrm{Cd}(\mathrm{U} 2 \mathrm{~S}-\mathrm{H})^{+}$[3] (see Fig. 1).

Conclusions regarding the structure of the $\mathrm{M}(\mathrm{C} 2 \mathrm{~S}-\mathrm{H})^{+}$ complexes

From the results in Fig. 6 and Table 3 it is evident that the stability enhancement is much larger for the $\mathrm{M}(\mathrm{C} 2 \mathrm{~S}-\mathrm{H})^{+}$ complexes than for $\mathrm{Cd}(\mathrm{U} 2 \mathrm{~S}-\mathrm{H})^{+}$. Indeed, in the 2-thiouridinate ligand of the latter complex the negative charge is to a significant part localized on N3 [3], which binds the metal ion; this is evidently not the case for the $\mathrm{M}(\mathrm{C} 2 \mathrm{~S}-\mathrm{H})^{+}$ species; in these instances the main binding site is clearly the thioate group (C2)S ${ }^{-}$(Fig. 2), which carries most of the negative charge. Hence, again several isomeric species (cf. Fig. 5) for the $\mathrm{M}(\mathrm{C} 2 \mathrm{~S}-\mathrm{H})^{+}$complexes need to be taken into account.

From solid-state crystal structure studies of complexes of (phosphine)gold(I) formed with 4-amino-2-pyrimidine thiolate, monodentate binding of the metal ion to the thiolate group is known [59], but the formation of fourmembered chelates to the same ligand (also known as 4amino-2-mercaptopyrimidine) involving both the $\mathrm{S}^{-}$and $\mathrm{N}$ sites has been observed as well in complexes formed with diorganotin(IV) compounds [60]. The corresponding type of four-membered rings is also found in complexes formed by (pentamethyl-cyclopentadienyl)rhodium(III) with pyrimidine-2-thionate or 4-methylpyrimidine-2-thionate [61]. Hence, the monodentate structure shown in Fig. 7b and the one with the four-membered chelate shown in Fig. 7c are most likely the important isomers of the $\mathrm{M}(\mathrm{C} 2 \mathrm{~S}-\mathrm{H})^{+}$species, also in aqueous solution, though the semichelate shown in Fig. 7d is another important candidate. The structure shown in Fig. 7a is clearly a species which occurs at best in trace amounts (see also "Considerations on the stability of the $\mathrm{M}(\mathrm{C} 2 \mathrm{~S}-\mathrm{H})$ complexes").

To conclude, it is evident that the primary binding site in $\mathrm{M}(\mathrm{C} 2 \mathrm{~S}-\mathrm{H})^{+}$complexes is the $(\mathrm{C} 4) \mathrm{S}^{-}$site. Indeed, if one carries out an evaluation corresponding to the one described for the $\mathrm{M}(\mathrm{C} 2 \mathrm{~S})^{2+}$ complexes, one arrives at the, not unexpected, result that sulfur binding to $(\mathrm{C} 2) \mathrm{S}^{-}$is even more important in the $\mathrm{M}(\mathrm{C} 2 \mathrm{~S}-\mathrm{H})^{+}$species than to $(\mathrm{C} 2) \mathrm{S}$ in the $\mathrm{M}(\mathrm{C} 2 \mathrm{~S})^{2+}$ complexes; in fact, in more than $99.99 \%$ of the complex species is the metal ion $(\mathrm{C} 2) \mathrm{S}^{-}$-coordinated.
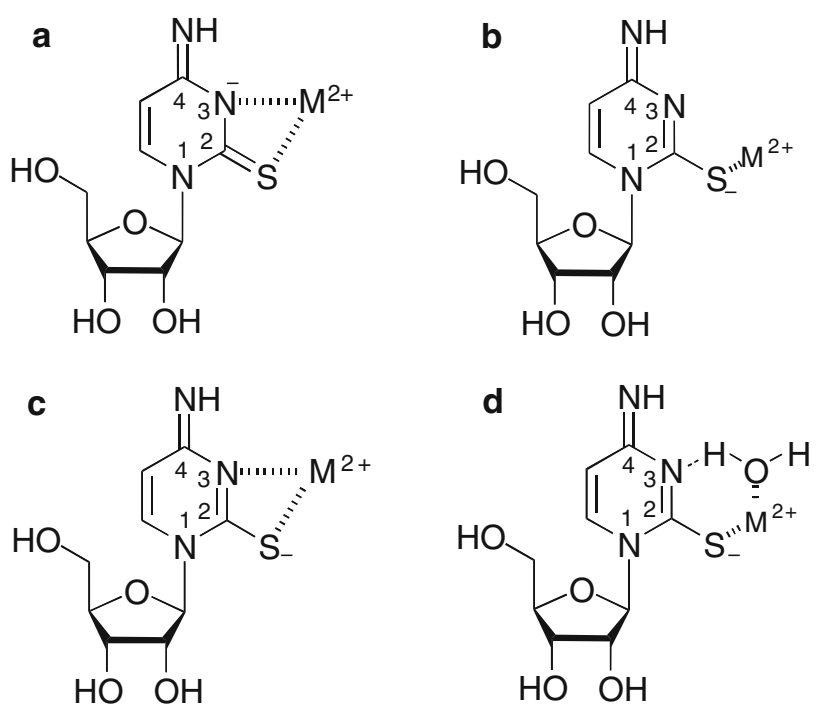

Fig. 7 Possible metal ion binding modes existing in equilibrium in aqueous solution of the $\mathrm{M}(\mathrm{C} 2 \mathrm{~S}-\mathrm{H})^{+}$complexes. The structure in $\mathbf{a}$ is certainly a minority species; for details see "Conclusions regarding the structure of the $\mathrm{M}(\mathrm{C} 2 \mathrm{~S}-\mathrm{H})^{+}$complexes"

\section{Conclusions}

$\mathrm{C} 2 \mathrm{~S}$ is a remarkable nucleoside analogue which differs from its parent, Cyd, in many respects, though in the neutral form their structures are very similar, i.e., $(\mathrm{C} 2)=\mathrm{O}$ is simply replaced by $(\mathrm{C} 2)=\mathrm{S}$ (Fig. 1), and indeed the connected change in basicity of $\mathrm{N} 3$ is of the expected order. However, the stability enhancements observed for the $\mathrm{M}(\mathrm{C} 2 \mathrm{~S})^{2+}$ complexes are much larger than those obtained for the corresponding $\mathrm{M}(\mathrm{Cyd})^{2+}$ species (Fig. 4, Table 2). This proves that for the $\mathrm{Zn}(\mathrm{C} 2 \mathrm{~S})^{2+}$ and $\mathrm{Cd}(\mathrm{C} 2 \mathrm{~S})^{2+}$ complexes no longer is N3 the stability-determining binding site, but that this is now $(\mathrm{C} 2)=\mathrm{S}$.

Another very significant difference between the two compounds is that the (C4)-amino group in $\mathrm{C} 2 \mathrm{~S}$ loses relatively easily a proton $\left(\mathrm{p} K_{\mathrm{a}}=12.65\right)$ in contrast to the situation in the parent nucleoside $\left(\mathrm{p} K_{\mathrm{a}} \approx 16.7\right)$ [37, 39]. However, the crucial point is that the deprotonation reaction in $\mathrm{C} 2 \mathrm{~S}$ is connected with a redistribution of charge and bond orders. This means it is concluded that the negative charge which results from the deprotonation of $(\mathrm{C} 4) \mathrm{NH}_{2}$ is thereafter largely located at the $(\mathrm{C} 2) \mathrm{S}^{-}$unit (Fig. 2). In accord with this conclusion are the following observations and reasonings: (1) the large acidification of the (C4) $\mathrm{NH}_{2}$ group due to the $\mathrm{S}$ substitution at $(\mathrm{C} 2) \mathrm{O}$ can in this way be explained; (2) the tremendous difference in acidity of more than $9 \mathrm{pK}$ units between the $(\mathrm{C} 4) \mathrm{NH}_{2}$ group in $\mathrm{C} 2 \mathrm{~S}$ and in $\mathrm{M}(\mathrm{C} 2 \mathrm{~S})^{2+}$ can only be rationalized if charge delocalization takes place and if $\mathrm{M}^{2+}$ coordination involves strongly the (C2) $\mathrm{S}^{-}$site; (3) the very large stability enhancement of about $8 \log$ units which is observed for the $\mathrm{M}(\mathrm{C} 2 \mathrm{~S}-\mathrm{H})^{+}$ 
complexes can be understood only by a $(\mathrm{C} 2) \mathrm{S}^{-} / \mathrm{M}^{2+}$ coordination; (4) as expected, in the case of a thiolate coordination, the stability of the $\mathrm{Cd}(\mathrm{C} 2 \mathrm{~S}-\mathrm{H})^{+}$complex is larger than that of the $\mathrm{Zn}(\mathrm{C} 2 \mathrm{~S}-\mathrm{H})^{+}$one.

The fact that with metal ions like $\mathrm{Zn}^{2+}$ the deprotonation reaction discussed in the preceding paragraph takes place at a $\mathrm{pH}$ close to 3, i.e., far below the physiological $\mathrm{pH}$ range, has consequences. For example, in a transfer RNA which contains $\mathrm{C} 2 \mathrm{~S}$, the hydrogen-bonding pattern will be strongly affected, not to speak of the tremendous metal ion affinity which develops upon the indicated deprotonation reaction. This may be one of the reasons why $\mathrm{C} 2 \mathrm{~S}$ and its derivatives show promising potentials as drugs $[5,10,11]$.

Finally, it may be pointed out that metal ions like $\mathrm{Mg}^{2+}$ which have a very low thiophilicity, in contrast to $\mathrm{Zn}^{2+}$, which was studied here, can still have significant effects in a biological system. There is no need to acidify $\mathrm{C} 2 \mathrm{~S}$ down to $\mathrm{pH} \mathrm{3}$; an acidification into the $\mathrm{pH}$ range 7-8 is enough and for this a Coulombic interaction between $(\mathrm{C} 2) \mathrm{S}^{-}$and a "hard" metal ion like $\mathrm{Mg}^{2+}$ is good enough to achieve the acidification and tautomerization. That metal ion coordination, e.g., even of $\mathrm{Na}^{+}$, can affect nucleobase tautomerizations was recently concluded on the basis of theoretical calculations [62].

Acknowledgments The competent technical assistance of Astrid Sigel in the preparation of the manuscript and the support by the Universities of Basel and Wroclaw are gratefully acknowledged.

\section{References}

1. Dubler E (1996) Met Ions Biol Syst 32:301-338

2. Iranzo O, Khalili H, Epstein DM, Morrow JR (2004) J Biol Inorg Chem 9:462-470

3. Odani A, Kozlowski H, Swiatek-Kozlowska J, Brasún J, Operschall BP, Sigel H (2007) J Inorg Biochem 101:727-735

4. Raj CR, Behera S (2005) Biosens Bioelectron 21:949-956

5. Van Rompay AR, Norda A, Lindén K, Johansson M, Karlsson A (2001) Mol Pharmacol 59:1181-1186

6. Leipuviene R, Qian Q, Björk GR (2004) J Bacteriol 186:758-766

7. Lukovits I, Kalman E, Zucchi F (2001) Corrosion 57:3-8

8. Zhang X-H, Wang S-F (2005) Sens Actuators B 104:29-34

9. Zhang X-H, Wang S-F, Sun N-J (2004) Bioelectrochem 65:41-46

10. Shigeta S, Mori S, Watanabe F, Takahashi K, Nagata T, Koike N, Wakayama T, Saneyoshi M (2002) Antivir Chem Chemother 13:67-82

11. Kawaguchi T, Ichikawa T, Hasegawa T, Saneyoshi M, Wakayama T, Kato H, Yukita A, Nagata T (2000) Chem Pharm Bull 48:454-457

12. Van Rompay AR, Johansson M, Karlsson A (1999) Mol Pharmacol 56:562-569

13. Sigel H (2004) Chem Soc Rev 33:191-200

14. Sigel H (1999) Pure Appl Chem 71:1727-1740

15. Sigel H, Griesser R (2005) Chem Soc Rev 34:875-900

16. Civcir PÜ (2001) J Phys Org Chem 14:171-179

17. Davies DB, Rajani P, Sadikot H (1985) J Chem Soc Perkin Trans 2:279-285

18. Aoki K (1996) Met Ions Biol Syst 32:91-134
19. Lauhon CT, Skovran E, Urbina HD, Downs DM, Vickery LE (2004) J Biol Chem 279:19551-19558

20. Lauhon CT (2002) J Bacteriol 184:6820-6829

21. Lundgren HK, Björk GR (2006) J Bacteriol 188:3052-3062

22. Pettit LD, Powell HKJ (2001) IUPAC stability constants database, release 5, version 5.16. Academic Software, Timble, Otley, West Yorkshire, UK

23. Smith RM, Martell AE (2003) NIST critically selected stability constants of metal complexes, reference database 46; version 7.0. US Department of Commerce, National Institute of Standards and Technology, Gaithersburg, MD, USA

24. Murray K, May PM (2001) Joint expert speciations system (JESS), version 6.4. Division of Water Technology, CSIR, Pretoria, South Africa, and School of Mathematical and Physical Sciences, Murdoch University, Murdoch, Western Australia

25. Knobloch B, Sigel H (2004) J Biol Inorg Chem 9:365-373

26. Kinjo Y, Ji L-n, Corfù NA, Sigel H (1992) Inorg Chem 31:55885596

27. Gans P, Sabatini A, Vacca A (1985) J Chem Soc Dalton Trans: $1195-1200$

28. Aragoni MC, Arca M, Crisponi G, Nurchi VM (1995) Anal Chim Acta 316:195-204

29. Yamauchi O, Odani A, Masuda H, Sigel H (1996) Met Ions Biol Syst 32:207-270

30. Scheller KH, Hofstetter F, Mitchell PR, Prijs B, Sigel H (1981) J Am Chem Soc 103:247-260

31. Kowalik-Jankowska T, Varnagy K, Swiatek-Kozlowska J, Jon A, Sóvágó I, Sochacka E, Malkiewicz A, Spychala J, Kozlowski H (1997) J Inorg Biochem 65:257-262

32. Swiatek-Kozlowska J, Brasuń J, Dobosz A, Sochacka E, Glowacka A (2003) J Inorg Biochem 93:119-124

33. Pogorelyi VK, Barvinchenko VN, Lobanov VV (1979) Teor Eksp Khim 15:547-552

34. Song B, Sigel RKO, Sigel H (1997) Chem Eur J 3:29-33

35. Da Costa CP, Krajewska D, Okruszek A, Stec WJ, Sigel H (2002) J Biol Inorg Chem 7:405-415

36. Sigel H, Martin RB (1994) Chem Soc Rev 23:83-91

37. Lippert B (2005) Prog Inorg Chem 54:385-447

38. Sigel RKO, Sigel H (2007) Met Ions Life Sci 2:109-180

39. Stewart R, Harris MG (1977) Can J Chem 55:3807-3814

40. Housecroft CE, Sharpe AG (2001) Inorganic Chemistry. Pearson Education Ltd, Harlow, UK, p 37

41. Podolyan Y, Gorb L, Blue A, Leszczynski J (2001) J Mol Struct (Theochem) 549:101-109

42. Bereket G, Öğretir C, Yaman M, Hür E (2003) J Mol Struct (Theochem) 625:31-38

43. Steger E, Martin K (1963) Z Anorg Allg Chem 323:108-113

44. Steger E, Martin K (1961) Z Anorg Allg Chem 308:330-336

45. Frey PA, Reimschüssel W, Paneth P (1986) J Am Chem Soc 108:1720-1722

46. Frey PA, Sammons RD (1985) Science 228:541-545

47. Sigel H (2004) Pure Appl Chem 76:1869-1886

48. Griesser R, Kampf G, Kapinos LE, Komeda S, Lippert B, Reedijk J, Sigel H (2003) Inorg Chem 42:32-41

49. Garijo Añorbe M, Lüth MS, Roitzsch M, Morell Cerdà M, Lax P, Kampf G, Sigel H, Lippert B (2004) Chem Eur J 10:1046-1057

50. Kapinos LE, Sigel H (2002) Inorg Chim Acta 337:131-142

51. Martin RB, Sigel H (1988) Commun Inorg Chem 6:285-314

52. Sigel RKO, Song B, Sigel H (1997) J Am Chem Soc 119:744-755

53. Da Costa CP, Okruszek A, Sigel H (2003) Chembiochem 4:593602

54. Sánchez-Moreno MJ, Fernández-Botello A, Gómez-Coca RB, Griesser R, Ochocki J, Kotyński A, Niclós-Gutierrez J, Moreno V, Sigel H (2004) Inorg Chem 43:1311-1322

55. Sigel H, Massoud SS, Song B, Griesser R, Knobloch B, Operschall BP (2006) Chem Eur J 12:8106-8122 
56. Aoki K, Saenger W (1984) J Inorg Biochem 20:225-245

57. Aoki K (1976) Biochim Biophys Acta 447:379-381

58. Knobloch B, Linert W, Sigel H (2005) Proc Natl Acad Sci USA 102:7459-7464

59. Wilton-Ely JDET, Schier A, Mitzel NW, Nogai S, Schmidbaur H (2002) J Organomet Chem 643-644:313-323
60. Ma C-L, Shi Y, Zhang Q-F, Jang Q (2005) Polyhedron 24:11091116

61. Yamanari K, Fukuda I, Yamamoto S, Kushi Y, Fuyuhiro A, Kubota N, Fukuo T, Arakawa R (2000) J Chem Soc Dalton Trans: 2131-2136

62. Hu X, Li H, Zhang L, Han S (2007) J Phys Chem B 111:9347-9354 